DOI https://doi.org/10.18551/rjoas.2018-07.41

\title{
THE DEVELOPMENT STRATEGY OF FISH PROCESSING INDUSTRY IN BANDA ACEH
}

\author{
Ernawaty* \\ Graduate Program, Syiah Kuala University of Banda Aceh, Indonesia \\ Indra, Ismayani \\ Faculty of Agriculture, Syiah Kuala University of Banda Aceh, Indonesia \\ *E-mail: ernawaty2019@gmail.com
}

\begin{abstract}
The purpose of this study is to analyze and determine the development strategy that can be recommended in the fish processing industry in Banda Aceh.The analyses used are SWOT and QSPM analysis. The calculation result shows IFE matrix is 3,540 and EFE matrix is 3,024 . Based on QSPM analysis results, there are 4 priority development strategies that can be recommended to the fish processing industry in the research area, i.e. perform diversification, promote, and innovate; increase human resource capacity through continuous coaching and training; establish partnership with other parties; strengthening and expanding local, national, and international markets.
\end{abstract}

\section{KEY WORDS}

Development, strategy, fish processing, business.

Processing of fresh / raw fish into processed fish is one form of handling of captured fish, to be durable and long lasting, but still favored by consumers and can also increase the value-added fishery products because at certain times the value of fish can be uneconomical where fish become decomposed and eventually thrown away if there is a surplus of marine fisheries production due to the lack of adequate supporting facilities such as ice factories, refrigerators, and fish processing factories.

The fish processing industry in Banda Aceh is still running conventionally, using only traditional technology, manual processing and the drying process still rely on sunlight. In that case, further research on the development strategy of the fish processing industry in the research area whether it can be one of the mainstay product of the region and become the processed type that can enrich the culinary in Aceh that can penetrate the industrial and overseas market, and increase the passion of the investor to invest in the research area so it will absorb many workers in the potential area in Banda Aceh and stimulate the growth of other fish processing industries, as well as improve the welfare of fishermen, processing businesses, workers, marketers of processed fish and also the surrounding community, so that the potential of this processed fishery can be a major driver of Aceh's economy in the future.

\section{METHODS OF RESEARCH}

This research was conducted in Banda Aceh, Aceh Province. The location determination was done with purposive sampling (Nasution, 2004), with the criterion that in the area is the area with fish processing industry. The objects of research are: the industry which process the sea fish into abon (shredded and dried fish), dendeng (jerked fish), and kayu fish bar; and related agencies. The scope of this research is the development strategy of marine fish processing industry.

The respondents are fish processor industries according to type of fish processing industry i.e. 2 respondents from abon processing industry; 2 respondents from dendeng processing industry; 4 respondents from kayu fish bar processing industry in the research area. The respondents from related offices are employees in charge to industrial and 
fisheries development in Banda Aceh. The method of determining the respondents was done with purposive sampling.

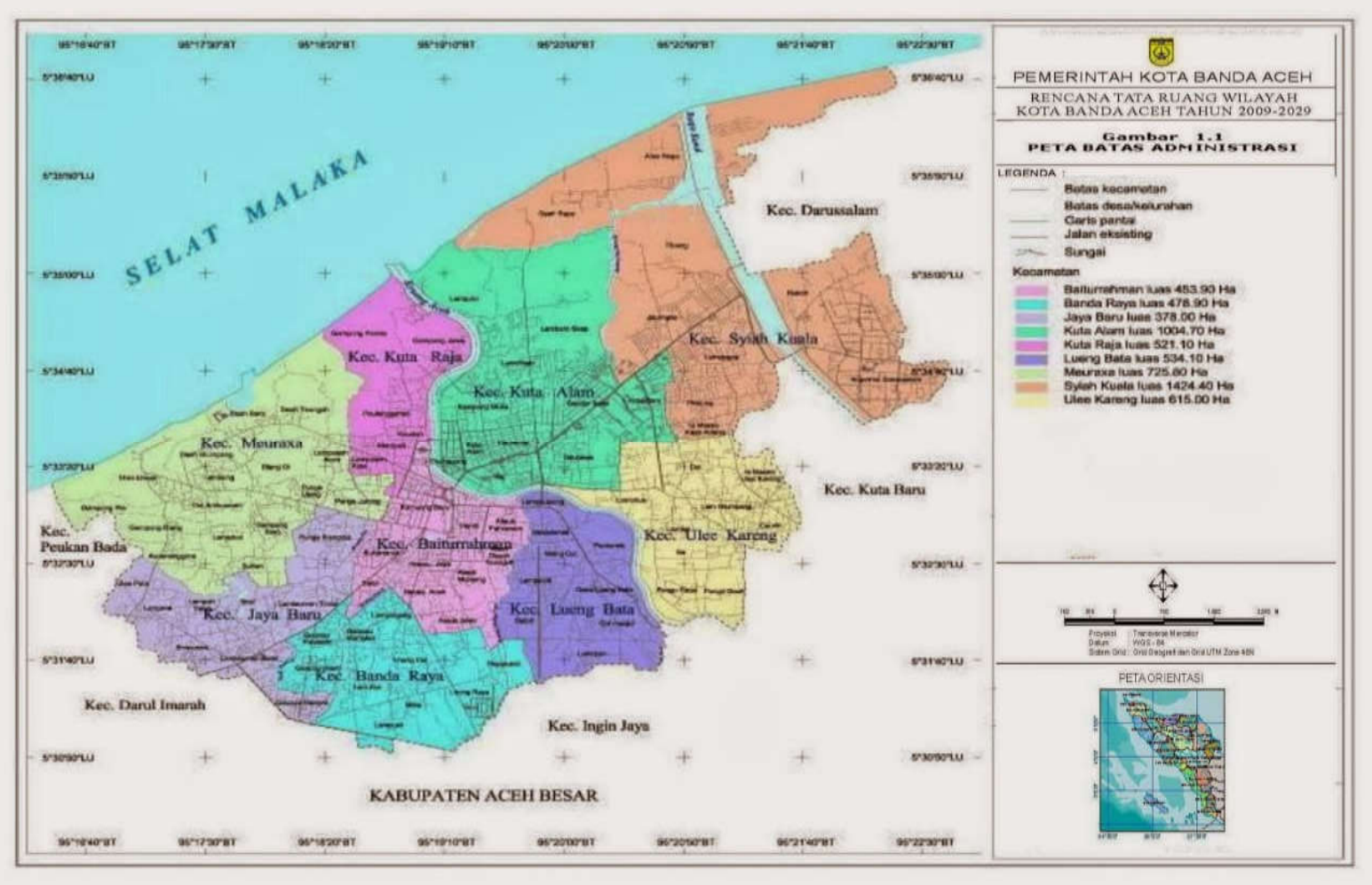

Figure 1 - Banda Aceh

The data collected in this study are consist of primary data and secondary data and arranged in such a way and corresponed to the needs of the analysis. Primary data obtained through direct observation and interviews with key informants by using the guided questionaires that have been prepared previously. Secondary data is obtained from books, journals, literature, internet, and government agencies related to research. The analyses used are the analysis of Strengths, Weaknesses, Opportunities, Threats (SWOT) and Quantitative Strategic Planning Matrix (QSPM).

\section{RESULTS AND DISCUSSION}

The fish processing business owner should be able to predict what will happen in the future by looking at what happened in the past, so that the processor industry can prepare various alternative strategies to overcome any problems that arise so it will survive in the fluctuating condition of the country's economy. Table 1 below is the SWOT quality measurement and rate of the fish processing industry in the study area.

Based on Table 1 above it can be seen that the use of quality raw materials have the highest quality value of 0.151 become the Strength of the fish processing industry, with rating 4 , and score 0.604 , because the quality of good raw materials will certainly produce a good product as well; while the highest Weakness factor is traditional technology processing with quality value of 0.109 , rating 4 , and score 0.438 , because the industry still rely on human-processing technology and minimal modern-technology assets; in the Opportunity factor, the highest quality measurement lies in the availability of abundant fish which is 0.150 , rating 4 , and score 0.601 , because the production process depends on the availability of fish supply; meanwhile for the biggest Threat factor the effect is the price of raw materials with the quality measurement of 0.138 , rating 3 and score 0.415 , because if the price of raw materials rises, the processing industry will reduce the volume of its production or raise the selling price of its products. 
Table 1 - SWOT Quality Measurement and Rate

\begin{tabular}{|c|c|c|c|}
\hline Internal Strategic Factors & Quality & Rating & Score \\
\hline \multicolumn{4}{|l|}{ Strengths } \\
\hline 1. Using high quality raw materials & 0,151 & 4,000 & 0,604 \\
\hline 2. Strategic industrial location & 0,125 & 3,000 & 0,374 \\
\hline 3. Easy processing and fast production cycle & 0,140 & 3,000 & 0,419 \\
\hline 4. Availability of experienced worker & 0,136 & 4,000 & 0,543 \\
\hline 5. Good product quality and innovation & 0,143 & 4,000 & 0,574 \\
\hline Strengths Score & 0,694 & & 2,513 \\
\hline \multicolumn{4}{|l|}{ Weaknesses } \\
\hline 1. Traditional technology usage & 0,109 & 4,000 & 0,438 \\
\hline 2. Promotion & 0,113 & 3,000 & 0,340 \\
\hline 3. Waste management & 0,083 & 3,000 & 0,249 \\
\hline Weaknesses Score & 0,306 & & 1,026 \\
\hline Difference (Strengths - Weaknesses) & & & 1,487 \\
\hline Total & 1,000 & & 3,540 \\
\hline \multicolumn{4}{|l|}{ External Strategic Factors } \\
\hline \multicolumn{4}{|l|}{ Opportunities } \\
\hline 1. Government support & 0,134 & 3,000 & 0,403 \\
\hline 2. Abundant availability of fish & 0,150 & 4,000 & 0,601 \\
\hline 3. Market & 0,138 & 3,000 & 0,415 \\
\hline 4. $\quad$ Partnership with other parties & 0,099 & 3,000 & 0,296 \\
\hline OpportunitiesScore & 0,522 & & 1,715 \\
\hline \multicolumn{4}{|l|}{ Threats } \\
\hline 1. Competitor & 0,111 & 3,000 & 0,332 \\
\hline 2. Weather/Climate & 0,126 & 2,000 & 0,253 \\
\hline 3. Effect of the government's economic policy & 0,103 & 3,000 & 0,308 \\
\hline 4. Raw material prices & 0,138 & 3,000 & 0,415 \\
\hline Threats Score & 0,478 & & 1,308 \\
\hline Difference (Opportinities - Threats) & & & 0,407 \\
\hline Total & 1,000 & & 3,024 \\
\hline
\end{tabular}

Source: Primary Data Processed 2017.

The source of fish taken from the Pelabuhan Perikanan Samudera Lampulo (Ocean Fishing Port; PPS) which is located not far (from 1 to $5 \mathrm{Km}$ ) from the industrial location and does not take a long time to transport the fish raw materials so the quality is maintained and minimize the transportation cost. The processor industry can ensure the use of good (even best) quality raw materials fish to produce the processed products because the Dinas Kelautan dan Perikanan (Department of Marine and Fisheries; DKP) Aceh in accordance with the Management of PPS Lampulo continues to increase the examination of the use of formalin, rodhamin and borax (dangerous fish preservatives) on fish, shrimp and other biota sold by traders in the PPS. According to the Head of DKP Aceh, the monthly supervision is stricted become twice a week, every Tuesday and Thursday at 07.30 to 10.00 WIB (Serambi Indonesia, 2017).

Fish processing process is quite easy because it using simple technology which can be done manually using human power and does not take a long time because it can be done 1 to 3 days including drying process for dendeng and kayu fish if only rely on sunlight, even for kayu fish the proccess can shortened by $1 / 2$ day using sunlight and another $1 / 2$ day by using fogging; whileabon can be produced 1 day for 1 cycle of production. According Heruwati (2002) the fish processing activities in Indonesia are still classified as traditional fish processing and carried out on the scale of the home industry.

The fish processor industry owner has been running the fish processing industry for a long time -about 4-11 years- so she has been experienced with it. This fish processing industry has 2 to 4 workers who are always available in the business location, consisting of the owner himself, his family members, and the community around the business location.

The good quality processed fish products must have been known for most people, especially among culinary entrepreneurs in Banda Aceh such as food stalls, restaurants, and catering. They have become regular customers of these processors industry owners. The products have also been included in several exhibitions organized by the relevant agencies. Existing products such as innovation already packaged have been sold in souvenir shops 
around Banda Aceh such as in Peunayong and Pasar Aceh. The promotion is generally only mouth to mouth (natural promotion proccess), so in the future it needs better promotion to improve its existence in the community so that the products are better known, sought, and purchased to increase its sales volume, so the industry income will also increase.

The geographical location of Banda Aceh may become an opportunity for the fish processing industry, in accordance with what was put forward by Putri et al. (2017) that Banda Aceh, which the area is mostly surrounded by ocean, has abundant sea produce, especially captured fish. Data of 2015 obtained from Badan Pusat Statistik (Central Bureau of Statistics; BPS) (2016) shows that the value of fishery production in Banda Aceh City for marine fishery subsector as much as Rp. 111.756 million. This is supported by the availability of adequate number of boat fleets in Banda Aceh as a vital equipment of supporting the result of captured fish of marine resources. The number of ships available in Banda Aceh City in 2012 is 423 units, 542 units in 2013, 2013 at 673 units, and 512 units in 2015 (Bappeda; Development Planning Agency at Sub-National Level of Aceh, 2016 ${ }^{\text {) }}$.

The policies of eradicating illegal fishing (one of them is done by drowning the foreign ships and ex-foreign shps) as a distinct step in the proccess implementation of Law no. 45 of 2009 on Fisheries to save fish resources at sea. This is one form of many support provided by the government to maintain the sustainability of fishery business in Indonesia including fish processing industry, because the rampant illegal fishing becomes one of the detentions in optimizing the marine resources in Indonesia. According to http://en.beritasatu.com in Nasirin and Hermawan (2017) states that due to illegal, unreported, and unregulated fishing (IUU fishing) Indonesia expreienced a great loss, in line with that statement the Direktorat Jenderal Pengawasan Sumber Daya Kelautan dan Perikanan Kementrian Kelautan dan Perikanan (Directorate General of Supervision of Marine Resources and Fisheries of Marine and Fisheries Ministry; Ditjen PSDKP-KKP), Indonesia losses estimated Rp. 101,040 trillion / year due to IUU Fishing. Thus, the policy has had a positive impact on the sustainability of current marine resources; the increase of fish resources after the implementation of illegal fishing eradication policy that is with the increase of fish production landed at PPS Lampulo in 2015 as many as 11,105,093 Kg; and in 2016 as many as 12,579,921 $\mathrm{Kg}$ (The Technical Implementation Unit; UPTD PPS Lampulo, 2017).

The owners of these fish processing industries should continue to develop their potential, either independently or integrated by following coaching and training organized by government and private parties, especially in technology, management and marketing in order to improve the quality of industry in their business to increase profit. The training which ever been given is in the training on how to make drying fish; how to process fish according to the type of fish each processing steps; packaging; promotion product. The training was organized by the Dinas Pangan Pertanian Kelautan dan Perikanan (Department of Food Marine and Fisheries; DPPKP) and Dinas Kelautan dan Perikanan (Department of Marine and Fisheries; DKP) located inside and outside Banda Aceh such as Jakarta and Belawan, Medan. Among the interviewed respondents, there has been a trainer for beginner entrepreneurs. This can be used as an regional asset of human resources (HR) that must continue upgrading the knowledge in order to continue tranferring knowledge to others who want to involved in the same business.

With the encouragement of Banda Aceh as a tourist destination for the last few years, increasing the number of domestic and foreign tourists who come to visit Banda Aceh it can be seen that from year to year the domestic and foreign tourists who visit Banda Aceh City continues to increase: in 2012 as many as 176,965 people, in 2013188.035 people, in 2014 as many as 236,042 people and in 2015 reached 266,929 (Bappeda; Development Planning Agency at Sub-National Level of Aceh, 2016 ). This could make it a market opportunity for the fish processing industry to grow because the products can be used by tourists to take home their home country.

The number female workers (according to BPS number of female civil servants in 2015 are as many as 3859 people), the lack of consumers' time to prepare the type of food that takes a long time in the making proccess, causing many consumers, especially those who work, prefer practical food (convenient, fast and easy) more than self-processing food, it is in 
accordance with what is submitted by Direktorat Pengolahan Hasil (Directorate of Processing Results) (2013): the development of value-added fishery products become something that must be done, this is due to the shifts that occur in the community, i.e: a) the changes of lifestyle ; b) changes in consumption patterns; c) the number of female workers; d) consumers prefer a more practical product and have a longer shelf-time. This is also in line with the results obtained by Karuniawati et al. (2017) that a female worker have higher frequency of purchasing processed fish compared to unemployed woman. According to BPS (2016) data, the average of consumption per capita for food of Banda Aceh's population, especially fish in 2014 is Rp. 82,597 and in 2015 of Rp. 73,732, this is the second largest expenses after expenses on practical food.

Table 2 - SWOT Matrix of Fish Processing Industry in Research Area

\begin{tabular}{|c|c|c|}
\hline EFE & $\begin{array}{l}\text { STRENGTHS (S) } \\
\text { Using high quality raw materials (S1) } \\
\text { Strategic industrial location (S2) } \\
\text { Easy processing and fast production } \\
\text { cycle (S3) } \\
\text { Availability of experienced worker (S4) } \\
\text { Good product quality and innovation } \\
\text { (S5) }\end{array}$ & $\begin{array}{l}\text { WEAKNESSES (W) } \\
\text { Traditional technology usage (W1) } \\
\text { Promotion (W2) } \\
\text { Waste management (W3) }\end{array}$ \\
\hline $\begin{array}{l}\text { OPPORTUNITIES (O) } \\
\text { Government support (O1) } \\
\text { Abundant availability fish } \\
\text { (O2) } \\
\text { Market (O3) } \\
\text { Partnership with other } \\
\text { parties (O4) }\end{array}$ & $\begin{array}{l}\text { Strategy SO } \\
\text { Product Diversification (S1, S4, S5, O1, } \\
\mathrm{O} 2, \mathrm{O} 3, \mathrm{O} 4) \\
\text { Market expansion and strengthening } \\
\text { through partnership ( } 1, \mathrm{~S} 2, \mathrm{~S} 3, \mathrm{~S} 4 \text {, } \\
\mathrm{S} 5, \mathrm{O} 1, \mathrm{O} 2, \mathrm{O} 3, \mathrm{O} 4) \\
\text { Continuous capacity building of human } \\
\text { resources either independently or by } \\
\text { related parties (S4, S5, O1, O4) }\end{array}$ & $\begin{array}{l}\text { Strategy WO } \\
\text { Responsive to information and modern } \\
\text { technology(W1, W2, W3, O1, O4) } \\
\text { Cooperate with both private or } \\
\text { government investors, and } \\
\text { academics(W1, W2, W3, O1, O2, O3, } \\
\text { O4) }\end{array}$ \\
\hline $\begin{array}{l}\text { THREATS (T) } \\
\text { Competitors (T1) } \\
\text { Weather/Climate(T2) } \\
\text { Effect of the government's } \\
\text { economic policy (T3) } \\
\text { Raw material prices (T4) }\end{array}$ & $\begin{array}{l}\text { Strategy ST } \\
\text { Product Quality Improvement (S1, S5, } \\
\text { T1, T3) } \\
\text { Development of production innovation, } \\
\text { packaging and marketing (S2, S5, S4, } \\
\text { T1, T2, T3, T4) }\end{array}$ & $\begin{array}{l}\text { Strategy WT } \\
\text { Alternative drying technology (W1, T2) } \\
\text { Carry out promotion towards both old } \\
\text { and new customers (W2,T1, T3) } \\
\text { Waste processing becomes a new } \\
\text { product (W3, } \mathrm{T} 1, \mathrm{~T} 3)\end{array}$ \\
\hline
\end{tabular}

Source: Primary Data Processed 2017.

The number of owner who run the same industry causes the ownwe may compete in purchasing of raw materials. The same demand for raw materialst is likely to be a threat to the continuity the production process due to inreasing price and limited access to raw materials. The Masyarakat Ekonomi ASEAN (ASEAN Economic Community; MEA), giving access to overseas products (arround Southeast Asian countries) will be easier to enter Indonesia. If the local product is not able to compete it will soon disappear from circulation because it is unable to compete with imported products. This is in accordance with Wiranta (2015) who argued that weak bureaucracy support and technological backwardness is also a problem that causes the competitiveness of Usaha Mikro Kecil dan Menengah (Micro, Small and Medium Enterprises; UMKM) difficult to move up. It cannot even compete in overseas, when in the country alone is less marketable.

The fish processing industry must have various strategical alternative in the development of its business in order to face various challenges to survive in a fluctuating Indonesian economy. So the strategy that must be executed fish processing which consists of 10 strategies can be reclassified into 4 strategies as follows:

- Perform diversification, promotion and innovation;

- Escalate HR capacity through continuous coaching and training;

- Strengthening and expanding local, national and international markets;

- Establish partnership with other parties. 
Table 3 - Results of QSPM Analysis (STAS Value) Priority Choice of Development Strategy of Fish Processing Industry in Research Area

\begin{tabular}{llll}
\hline \hline No & Priority Strategy & STAS & Rank \\
\hline 1 & Perform diversification, promotion and innovation & 6,278 & I \\
\hline 2 & Escalate HR capacity through continuous coaching and training & 6,101 & II \\
\hline 3 & $\begin{array}{l}\text { Strengthening and expanding local, national and international } \\
\text { markets }\end{array}$ & 5,867 & IV \\
\hline 4 & Establish partnership with other parties & 5,924 & III \\
\hline \hline
\end{tabular}

Source: Primary Data Processed, 2017.

STAS = Sum Total Attractiveness Score.

Based on QSPM analysis, 4 strategies of development strategy and its activities which can be recommended to fish processing industry in Banda Aceh are as follows:

- Perform diversification, promotion and innovation:

Perform quality control to maintain product quality from raw material selection to packaging; diversify products by making product variants: fish nuggets, otak-otak (grilled fish cake), kerupuk ikan (fish crackers), kerupuk tulang (bone crackers), ikan kayu crispy, bakso ikan (fish meatballs), kaki naga (fish drumstick); so that the consumer can choose the products according to their needs and tastes. Innovation can be done by adding flavor variants: original, sweet, spicy; for the industries that already have packaging to make more attractive packaging, including Label Halal Majelis Ulama Indonesia (Indonesian Council of Ulama; MUI) and product nutritional value, add recipes and cooking spices information in both inside and outside packaging. While for the industries that do not have packaging to make packaging attractive, hygienic and safe, so the product is secureded and durable, include product brand information, Label Halal Majelis Ulama Indonesia (Indonesian Council of Ulama; MUI) and product information (such as product weight, expiry time and composition). This is in accordance with the results of research Effendi et al. (2016) that packaging designs influence purchasing decisions with the most influential variables are packaging labels.

In terms of promotion in increasing sales, can be done by marketing products directly to consumers either in offices, schools, airports, terminals by using a cooking demo system, potential customers can see first hand how the process of cooking into fast food and can instantly taste it so they are expected to be interested in purchasing this product; promotion through advertising in the mass media, distribution of brochures in public places; participating exhibitions frequently.

- Escalate HR capacity through continuous coaching and training:

Basically the fish processing's owner in the research area have been coached trained by related agencies such as the Dinas Kelautan, Perikanan dan Pertanian Kota Banda Aceh (Department of Marine, Fisheries and Agriculture of Banda Aceh), Dinas Peindustrian Kota Banda Aceh (Departement of Industry of Banda Aceh), and Dinas Perikanan dan Kelautan Provinsi Aceh (Department of Fisheries and Marine of Aceh Province), but in this modern era and strong business competition the fish processing's owner should always improve their knowledge and skills either independently by reading books / literature, internet, or follow various counseling and training. Therefore, it is necessary to improve the human resources' capacity sustainably; this can be done by participating in: counseling, guidance, consultation, internship, as well as training on production techniques of simple financial management; product diversification; processing technology; packaging; promotion and marketing. Through coaching, training, continuous facilitation of human resources capacity of fish processing industry both in terms of knowledge and skills can continue to be upgraded as the times progress.

It is in accordance with Howara (2013) which suggests that based on the SWOT analysis, the first strategy should be done is to empower the community, through improvement of human resources by providing training, coaching and apprenticeship to fishery companies, so as to obtain high value-added products, which is healthy so that the processed products are able to reach all the destination areas. Hendratmoko et al. (2015), 
stated that find out the priority in the empowerment of fish processors can be done one of them with counseling, guidance, consultation, and training on fish processing techniques and business diversification in order to increase business so that processed products produced have high economic value, more hygienic processing methods and good quality with more modern technology so as to create product innovation.

- Establish partnership with other parties:

This strategy can be done by establishing and improving cooperation with government, private and academia; to create a good and creative business environment which can be done by establishing an active business group cooperation; guidance, supervision, counseling, mentoring from government and research recommendation from academia, for example find out the way of handling waste to be environmentally friendly or can become economical product, open access market information, technological innovation, sales promotion so as to produce quality products, safe for health and behavior in the market.

This is in accordance with Samadara et al. (2016) which stated that local governments and the public and private sector should be able to effectively identify, use existing resources and any means necessary to design and build the regional economy. The concept of partnership is a relationship of cooperation between business based on the principle of mutual support and mutual living based on the principle of kinship and togetherness. This partnership is one of the business strategies. Each of the actors involved directly must have a business ethic base that is understood and shared as a starting point in running the partnership.

- Strengthening and expanding local, national and international markets:

Strengthening the local market established through optimizing the marketing of local products. For local market strengthening, the government has a very important role to strengthen trade security in controlling imports to accommodate domestic products. In Kompas.com (2012) stated that according to the Secretary of the National Economic Committee, Indonesia's domestic market is still very potential until 2030. From the middle class factor with the character of high demand, the Indonesian market is very large. Based on data from the World Bank, Indonesia's middle class is 130 million people. While from the productive age (14-65 years), this is prevalent in all regions in Indonesia. $70 \%$ of Indonesian populations including productive age tend to have high purcashing power.

The market expansion can be done with the addition of new products that the community needs to complement existing products owned by the industry. This can be done by focusing on captive markets and more intensively on non captive markets. According to https://en.wikipedia.org, in Nugroho (2017) that the captive market is a market where potential consumers face the limitations of superior suppliers. The only option they have is to buy what is available or not to buy at all. Airports, hotels and terminals are alsoincluded in the captive market. Given the limited competition between suppliers in such places, the product can be sold at a high price.

Being a supplier of instant processed fish products during the Hajj season can also be done where currently the Hajj pilgrims will bring special food especially from the region of origin to meet their consumption needs while in Saudi Arabia. This will be a great opportunity for fish processors to meet the demand for these products because the numbers of Hajj pilgrims every year tend to increase. The following data reinforces the statement: According to Analisa news (Novandi, 2017) that the province of Aceh received an additional 1,282 quota of Hajj pilgrims by 2017 . With the addition of this quota, it means that the hajj quota of Aceh during this pilgrimage to 4,393 people from previously only 3,111 people. So with the increase of Hajj quotas from year to year can make it as an opportunity for other fish processors industry, because according to expert respondents so far there is only one supplier for processed fish for Hajj pilgrims.

Improving and adding industrial infrastructure facilities such as using the internet, utilize applications such as Whatsapp, Facebook and BBM to further optimize the technology, which is done to speed up interconnection with colleagues or business partners so that business relationships can be done quickly, and efficient. 


\section{CONCLUSION}

Based on QSPM analysis, there 4 strategies of development strategy and its activities which can be recommended to fish processing industry in Banda Aceh, i.e. 1) Perform diversification, promotion and innovation, 2) Escalate HR capacity through continuous coaching and training, 3) Establish partnership with other parties, 4) Strengthening and expanding local, national and international markets.

\section{REFERENCES}

1. Badan Pusat Statistik. 2016. Banda Aceh Dalam Angka 2016. Banda Aceh.

2. Bappeda Kota Banda Aceh. 2016. Statistik Banda Aceh 2016. Banda Aceh.

3. Direktorat Pengolahan Hasil. 2013. Laporan Akuntabilitas Instansi Pemerintah (LAKIP). Ditjen PPHP Kementerian Pertanian, Jakarta.

4. Effendi, M., Humanica, G.O.F., dan Deoranto, P. 2016. Analisis Desain Kemasan Terhadap Keputusan Pembelian Keripik Buah di Kota Malang dengan Metode Partial Least Square. Prosiding: Seminar Nasional Asosiasi Profesi Teknologi Agroindustri (APTA) 2016. Jember 26-27 Oktober 2016.

5. Hendratmoko, C., Istiyanto, I., dan Kusasih, I.A.K.R. 2015. Pengembangan Model Pemberdayaan Bagi Pengolah Ikan Guna Meningkatkan Pendapatan (Studi Kasus pada Pengolah Ikan di Kabupaten Cilacap). Jurnal Paradigma Vol. 12, No. 02.

6. Heruwati, E.S.2002. Pengolahan Ikan secara Tradisional: Prospek dan Peluang Pengembangan. Jurnal Pusat Riset Pengolahan Produk dan Sosial Ekonomi Kelautan dan Perikanan. Vol 21 No 3.

7. Howara, D. 2013. Strategi Pengembangan Pengolahan Hasil Perikanan Di Kabupaten Donggala. Program Studi Agribisnis, Fakultas Pertanian, Universitas Tadulako. J. Agroland. 20(1): 75-81.

8. Karuniawati, T., Satria, A., dan Yuliati, L.N. 2017. Analisis Pembelian Ikan Segar dan Ikan Olahan Pada Ibu Bekerja dan Ibu Tidak Bekerja. Jur. IIm. Kel. \& Kons., Januari 2017, p : 59-70.

9. Kompas.com. 2012.http://ekonomi.kompas.com. Berita: Penguatan Pasar Lokal dan Diversifikasi Ekspor. Diakses tanggal 22 Januari 2018.

10. Nasution, S. 2004. Metode Research (Penelitian IImiah). Bumi Aksara, Jakarta.

11. Nasirin, C., dan Hermawan, D. 2017. Kontroversi Implementasi Kebijakan Penenggelaman Kapal dalam Rangka Pemberantasan Illegal Fishing di Indonesia.Spirit Publik. 12 (1): 9-24.

12. Novandi, I. 2017. Berita: Kuota Haji Aceh Bertambah 1.282 Orang. http://harian.analisadaily.com. Diakses tanggal 19 Januari 2018.

13. Nugroho. 2017. Captive Market. http://bnugroho.id/2017/05/06/captive-market. Diakses tanggal 3 Maret 2018.

14. Putri, A.S., Romano, dan Zakiah. 2017. Analisis Kepuasan dan Keputusan Terhadap Konsumsi Ikan Laut di Kota Banda Aceh (Studi Kasus di Pasar Peunayong). Jurnal IImiah Mahasiswa Pertanian Unsyiah. 2 (2): 183-194.

15. Samadara, S., Tuati, N.F., Sauw, H.M. 2016. Pemberdayaan Ekonomi Masyarakat Berbasis Kemitraan (Studi Kasus Nelayan Desa Sulamu Kabupaten Kupang). Jurnal Bisnis dan Manajemen Islam, Vol. 4 No. 1, Juni 2016.

16. Serambi Indonesia. 2017. Berita: PPS Lampulo Intensifkan Pemeriksaan Formalin. http://aceh.tribunnews.com. Diakses14 Januari 2018.

17. UPTD.Pelabuhan Perikanan Samudera Lampulo. 2017. Data Perkembangan Produksi Ikan Yang Didaratkan Di UPTD PPS Lampulo Pada Tahun 2016. Banda Aceh.

18. Wiranta, D.N.S. 2015. Penguatan Peran Pemerintah Daerah dalam Mendorong Pertumbuhan Ekonomi Lokal: Peluang dan Tantangan Masyarakat Ekonomi ASEAN (MEA) 2015. Jurnal Lingkar Widyaiswara. 2 (3): 33-50. 